\title{
Da melancolia ao saudosismo: manifestação em Cesário e atualização em Ramil
}

\author{
Luciano Fussieger
}

\begin{abstract}
Resumo: Este trabalho se pretende audacioso, pois propõe o paralelismo entre dois poemas separados por mais de um século. Um deles, o poema "O Sentimento dum Ocidental" de Cesário Verde, poeta português da metade do século XIX e o outro, o poema/canção "Ramilonga", do cancionista gaúcho Vitor Ramil, nosso contemporâneo. Este trabalho pretende mostrar que ambos os textos estão impregnados de um mesmo sentimento de melancolia, esta, fruto de uma reflexão ou constatação de um mundo perturbado e contraditório, que é sintetizado pelas figuras das cidades de Lisboa em Cesário e Porto Alegre em Ramil. A transformação do espaço urbano está explícita no poema de Cesário e é ferramenta importante para a compreensão do mesmo. Já em "Ramilonga" as transformações estão consolidadas ou latentes, mas as suas consequiências aparecem no já referido sentimento de melancolia. Em seguida, ensaiarei um cotejo do sentimento de melancolia, materializado em ambos os textos, provindo daí minha tese de que em ambos os poemas (e principalmente se tomarmos a obra de ambos os poetas num todo), vemos uma saída sendo apontada, a fuga para o horizonte, que simboliza, ao meu ver, um passado pastoril grandioso, ou seja, uma busca saudosista. Passado esse que para os poetas poderia se traduzir em futuro.
\end{abstract}

Palavras-chave: Poema; Cidade; Melancolia.

\begin{abstract}
The present works intends to be daring, for it proposes a parallelism between two poems separated by more than a century. One of them is the poem "O Sentimento de um Ocidental" ("Feeling of a Western man") by Cesário Verde, Portuguese poet from the mid $19^{\text {th }}$ century, and the other one is the poem /song "Ramilonga" by the gaúcho singer Vítor Ramil, our contemporary. The present essay intends to show that both texts are impregnated with the same feeling of melancholy, derived from a reflection or perception of a disturbed and contradictory world, which is summarized by the images of the city of Lisbon in Verde, and Porto Alegre in Ramil. The transformation of the urban space is explicit in Verde's poem, and it is an important key for the comprehension of the poem. In "Ramilonga" the transformations are whether consolidated or latent, but their consequences appear in the feeling of melancholy materialized in both texts. Considering this, I state that in both poems (and especially if we consider the whole production of both poets), we see a way out being indicated, the escape towards the horizon, which symbolizes, in my point of view, a glorious pastoral past, which for both poets could be turned into a future.
\end{abstract}

Keywords: Poem; City; Melancholy.

São todos movidos, ao mesmo tempo, pelo desejo de mudança - de autotransformação e de transformação do mundo em redor - e pelo terror da desorientação e da desintegração, e o terror da vida que se desfaz em pedaços. Todos conhecem a vertigem e o terror de um mundo no qual "Tudo que é sólido se desmancha no ar". (BERMAN, 1986, p.13)

\footnotetext{
* Luciano Fussieger é graduando em Letras pela UFRGS.
} 


\section{O sentimento dum Ocidental}

É submerso nesse ambiente extremamente contraditório, referido por Berman, da segunda metade do século XIX, que surge em Portugal, mais especificamente em Lisboa, a poesia de Cesário Verde. Poeta que materializará em versos o sentimento de um homem, mas que em certa medida é de todos os homens, frente a esse mundo que se transforma. Cesário nos apresenta uma poesia de imagens enclausuradas em um espaço-tempo histórico passado, mas que suscitam uma reflexão atual, pois o fenômeno da modernidade não se extinguiu e, ao contrário do que muitos pensam, continua atuante transformando tudo ao seu redor.

"O Sentimento dum Ocidental" é prova disso. De fato, este poema, considerado por muitos como um dos pilares em que se sustenta a poesia portuguesa, é uma obra admirável sob todos os pontos de vista. Tanto pela inovação temática quanto pela estrutura e beleza dos versos, o poema de Cesário Verde merece, no mínimo, atenção e consideração, tanto por parte da crítica quanto por parte do público leitor de poesia.

“O Sentimento dum Ocidental”, quanto à sua estrutura textual, é composto por quarenta e quatro estrofes (quadras de rima A-B-B-A) divididas em quatro partes iguais, de onze estrofes cada uma. Quanto ao estilo, Cesário usa um método descritivo quase que "etnográfico". Em grande parte de seus poemas, incluindo-se aí "O Sentimento dum Ocidental", ele se utiliza de uma câmera imaginária e se põe como diretor de um documentário. Assim, podemos encarar "O Sentimento dum Ocidental" como um documentário em verso de uma Lisboa (que é pano de fundo histórico do poema) de meados do século XIX. Todas as transformações físicas, bem como as relações humanas, são captadas pela lente de Cesário e cristalizadas em seus versos. O passeio pela cidade, feito pelo eu lírico, nos é transmitido pelas imagens urbanas por ele captadas. Nos colocamos como verdadeiros espectadores e somos levados, pela subjetividade que capta a realidade e a retem com sua arte, a ter um panorama deste ambiente onde ele transita. Analisemos melhor esse roteiro cinematográfico.

Cesário Verde inicia o poema nomeando a primeira parte de "Ave-marias", fazendo referência ao final da tarde, mais especificamente às 18 horas. E é assim que ele nos descreve esta parte do dia:

Nas nossas ruas, ao anoitecer,

Há tal soturnidade, há tal melancolia,

Que as sombras, o bulício, o Tejo, a maresia

Despertam um desejo absurdo de sofrer. (VERDE, 1964, p.103) 
Nota-se nestes versos que a cidade se reveste de uma atmosfera suspensa. O anoitecer desperta no eu lírico, que sente esta suspensão da atmosfera, "um desejo absurdo de sofrer". A pergunta que nos cabe é porque esse desejo, uma quase necessidade, de sofrer, se o próprio eu lírico o considera absurdo? Seguindo-se no poema temos na estrofe seguinte o início de uma série de imagens, que nos vão pintando a Lisboa vivida e sentida pelo eu lírico.

O céu parece baixo e de neblina,

O gás extravasado enjoa-nos, perturba;

E os edifícios, com as chaminés, e a turba,

Toldam-se duma cor monótona e londrina. (VERDE, 1964, p.103)

Os dois primeiros versos da terceira estrofe nos fornecem um detalhe importante para pensarmos uma resposta, satisfatória, à pergunta acima feita. Assim nos diz o poeta:

Batem os carros de aluguer, ao fundo,

Levando à via férrea os que se vão. Felizes!

Ocorrem-me em revista, exposições, países:

Madrid, Paris, Berlim, S. Petersburgo, o mundo! (VERDE, 1964, p.103)

O fato interessante nos versos acima é a adjetivação com a qual o poeta recobre aqueles que se vão nos "carros de aluguer" à via férrea (que era na época, sem dúvida alguma, a saída da cidade, a ligação com o exterior). Segundo o eu lírico, eles se vão "Felizes!". Seria essa felicidade uma constatação pura e simples da realidade que o poeta vê? Ou seria essa felicidade um elemento que a subjetividade do poeta agrega a todos os que se vão? Sigamos à quarta estrofe.

Semelham-se a gaiolas, com viveiros,

As edificações somente emadeiradas:

Como morcegos, ao cair das badaladas,

Saltam de viga em viga os mestres carpinteiros. (VERDE, 1964, p.103)

Aqui temos a sequiência das imagens materiais da cidade que cresce. Não podemos deixar de ter em mente que Cesário Verde se situa num contexto histórico de transformações sociais e urbanas intensas ${ }^{1}$, não permanecendo inume perante estas. É como podemos compreender a analogia, feita pelo eu lírico, entre gaiolas, viveiros e os edifícios em construção. Os dois versos finais da quarta estrofe introduzem o início de uma sucessão de imagens, de outro elemento da cidade em intensa construção; os operários. Estes aparecem também no início da quinta estrofe.

Voltam os calafates, aos magotes,

De jaquetão ao ombro, enfarruscados, secos;

Embrenho-me, a cismar, por boqueirões, por becos,

Ou erro pelos cais a que se atracam botes. (VERDE, 1964, p.104)

\footnotetext{
${ }^{1}$ Para uma melhor visualização destas transformações é indispensável a leitura de José Mattoso e de sua História de Portugal. Nela podemos encontrar uma descrição densa do contexto econômico, político, ideológico, artístico, cultural e social vividos por Cesário Verde. ( MATTOSO. 1990,v.5 )
} 
No último verso acima vemos introduzida a imagem do cais por onde erra o eu lírico. Este espaço da cidade torna o nosso "guia" nostálgico de uma época passada, saudoso de outros tempos.

E evoco, então, as crónicas navais:

Mouros, baixéis, heróis, tudo ressuscitado!

Luta Camões no Sul, salvando um livro a nado!

Singram soberbas naus que eu não verei jamais! (VERDE, 1964, p.104)

Da sexta para a sétima estrofe temos uma quebra brusca de imagens.

E o fim da tarde inspira-me; e incomoda!

De um couraçado inglês vogam os escaleres;

E em terra num tinir de louças e talheres

Flamejam, ao jantar, alguns hotéis da moda. (VERDE, 1964, p.104)

O eu lírico retoma súbito sua descrição da cidade, vindo de um devaneio. Essa quebra nas imagens descritas no final da quinta estrofe e início da sétima nos leva a imaginar a sexta estrofe como um flash-back, mantendo viva assim nossa analogia com o cinema. Aspecto sutil, mas extremamente interessante, é o que depreendemos do $1^{\circ}$ verso da $7^{\circ}$ estrofe. Ao mesmo tempo em que o fim da tarde instiga o poeta, este fim "incomoda!". Mas por quê?. Temos que relembrar os outros questionamentos que o poeta já nos levou a fazer, e ter sempre em mente que tudo provém dum sentimento que inunda o texto, a melancolia. Na seqüência do poema temos uma série de imagens pintando tipos sociais que se movimentam ao final do dia.

Num trem de praça arengam dois dentistas,

Um trôpego arlequim braceja numas andas;

Os querubins do lar flutuam nas varandas;

Às portas, em cabelo, enfadam-se os lojistas!

Vazam-se os arsenais e as oficinas,

Reluz, viscoso, o rio; apressam-se as obreiras;

E num cardume negro, hercúleas, galhofeiras,

Correndo com firmeza, assomam as varinas.

Vêm sacudindo as ancas opulentas!

Seus troncos varonis recordam-me pilastras;

E algumas, à cabeça, embalam nas canastras

Os filhos que depois naufragam nas tormentas.

Descalças! Nas descargas de carvão,

Desde manhã à noite, a bordo das fragatas;

E apinham-se num bairro aonde miam gatas,

E o peixe podre gera os focos de infecção! (VERDE, 1964, p. 104 a 105)

Destacam-se as fotografias da saída dos trabalhadores das fábricas. A crueza e o lirismo com que essa cena é descrita realmente nos chama a atenção. $O$ rio torna-se a 


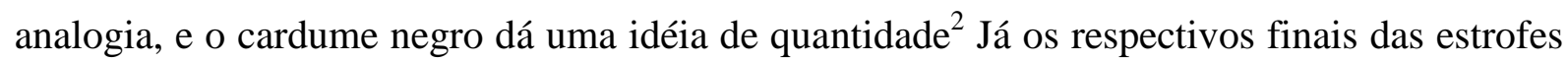
10 e 11 nos remetem a idéias presentes na época (final do século XIX), que passavam para a literatura. Seriam essas: o determinismo do meio (estrofe 10) e os bairros operários como o câncer das cidades (estrofe 11). Isso bem remete a romances naturalistas como $O$ Cortiço de Aluísio Azevedo, Germinal de Émille Zola, etc.

A segunda parte do poema intitula-se "Noite fechada". Segue nela o roteiro da lente minuciosa do eu lírico, que inicia essa nova parte com críticas sociais, destituindo-se um pouco do caráter neutro que tentava assumir para não corromper sua descrição.

Toca-se as grades, nas cadeias. Som

Que mortifica e deixa umas loucuras mansas!

O aljube, em que hoje estão velhinhas e crianças,

Bem raramente encerra uma mulher de "dom"! (VERDE, 1964, p.105)

Essa mulher de "dom" do último verso, que o poeta coloca em oposição às velhinhas e às crianças, nos afigura como uma mulher abonada, de posses. Se assim o virmos, temos nestes versos uma crítica ao sistema social e carcerário. Na estrofe seguinte este tom de crítica some e dá lugar ao velho ritmo melancólico.

E eu desconfio, até de um aneurisma

Tão mórbido me sinto,ao acender das luzes;

À vista das prisões, da velha sé, das cruzes,

Chora-me o coração que se enche e que se abisma. (VERDE, 1964, p.105)

Essa morbidez sentida pelo eu lírico aparece, como na $1^{\mathrm{a}}$ estrofe, frente a uma suspensão da atmosfera. Esta é provocada pelo acender das luzes. Imagem que nos remete a séculos passados, à figura do acendedor de lampiões, às luzes bruxuleantes de postes em meio à rua, que mal continham a escuridão. Os versos subseqüentes, da $14^{\mathrm{a}}$ estrofe, nos dão uma imagem da vida noturna da cidade e de seus bares e cafés.

A espaços, iluminam-se os andares,

E as tascas, os cafés, as tendas, os estancos

Alastram em lençol os seus reflexos brancos;

E a lua lembra o circo e os jogos malabares. (VERDE, 1964, p.105)

A $15^{\mathrm{a}}$ estrofe não deixa dúvida alguma quanto à parcialidade do eu lírico frente à Igreja. Esta recebe um certo desprezo, desferido sobre a figura do clero.

Duas igrejas, num saudoso largo,

Lançam a nódoa negra e fúnebre do clero:

Nelas esfumo um ermo inquisidor severo,

Assim que pela história eu me aventuro e alargo. (VERDE, 1964, p.105)

Já na $16^{\mathrm{a}}$ estrofe encontramos elementos para respondermos o porquê do sentimento

\footnotetext{
${ }^{2}$ Com efeito Mattoso traz dados quantitativos. A população de Lisboa, segundo ele, na década de 1870 girava em torno de 187.000. Já quanto ao número de trabalhadores fabris ele contabiliza cerca de 90.000 em todo Portugal, sendo que um quarto destes se localizavam em Lisboa.( MATTOSO. 1990, p. 495-496.)
} 
de melancolia que perpassa o poema.

Na parte que abateu no terremoto,

Muram-me as construções rectas, iguais, crescidas;

Afrontam-me, no resto, as íngremes subidas,

E os sinos dum tanger monástico e devoto. (VERDE, 1964, p.106)

O segundo verso, dentro dos acima transcritos, nos fornece uma idéia do sentimento do eu lírico frente à cidade. Ele se sente preso a esta no sentido de cárcere, pois, como ele mesmo diz, as construções "Muram-me".

Passando pelas estrofes 17 (onde o eu lírico passa por uma estátua de Camões, localizada numa praça de Lisboa), 18 (onde, num tom catastrófico, o poeta retoma, em parte, a idéia do bairro operário como berço das epidemias) e 19 (onde temos a imagem da ronda noturna saindo dos quartéis), chegamos, na $20^{\circ}$ estrofe, a um ponto interessante à análise.

Triste cidade! Eu temo que me avives

Uma paixão defunta! Aos lampiões distantes,

Enlutam-me, alvejando, as tuas elegantes

Curvadas a sorrir às montras dos ourives. (VERDE, 1964, p.106)

As duas frases iniciais dizem muito. Na primeira o poeta se expressa enquanto seu sentimento para com a cidade, que a essa altura já foi em grande parte descrito por ele em seu percurso. Para o eu lírico a cidade é triste, pois ela lhe aviva uma paixão defunta. Seria esta uma desilusão amorosa ou a morte real de uma pessoa amada? Ou poderia ser uma outra espécie de paixão, ideológica talvez? Perseguiremos essa idéia.

Quanto às estrofes 21 e 22, mais cenas urbanas: costureiras e floristas andando na rua e pessoas num bar passando o tempo a jogar dominó.

“Ao Gás” é como se intitula a terceira parte do poema “O Sentimento dum Ocidental”. A imagem do título nos remete às já citadas imagens de séculos passados, à luz bruxuleante que mal vence a escuridão. Isto retoma, novamente, uma atmosfera suspensa, onde os sentimentos afloram, mas não se definem com exatidão. E é para esta atmosfera que sai o eu lírico.

E saio. A noite pesa, esmaga. Nos

Passeios de lajedo arrastam-se as impuras.

Ó moles hospitais! Sai das embocaduras

Um sopro que arripia os ombros quase nus. (VERDE, 1964, p.107)

A segunda frase dos versos acima é, literalmente, a concretização da atmosfera que se mantinha suspensa. O poeta agora a sente. "A noite pesa, esmaga". A melancolia que segue presente nos versos é solidificada pela noite. Mesmo assim, segue o tour e os ensaios fotográficos e mais adiante nas estrofes 27 e 28 temos o uso da metalinguagem.

E eu, que medito um livro que exacerbe,

Quisera que o real e a análise mo dessem; 
Casas de confecções e modas resplandecem;

Pelas vitrines olha um ratoneiro imberbe.

Longas descidas! Não poder pintar

Com versos magistrais, salubres e sinceros,

A esguia difusão dos vossos reverberos,

E a vossa palidez romântica e lunar! (VERDE, 1964, p.108)

Temos aí gravado o momento exato de reflexão do eu lírico sobre seus versos, sobre sua arte. Temos de um lado o desejo dele de escrever um livro que exacerbasse, provavelmente, os limites da arte até então. Vemos também que ele identifica a realidade e a análise dessa como matéria de poesia. Só que nos versos da estrofe 28 ele se desilude diante da incapacidade de aprender a realidade em sua forma plena (velho ideal realista). Temos aqui um exemplo do uso da metalinguagem, a poesia falando da poesia. O produto disso tudo parece ser mais um elemento para pensarmos a cerne do sentimento de melancolia presente no poema, finalidade última dessa análise. Será que esse sentimento não tem uma ponta de origem nessa incapacidade do eu lírico de se expressar como ele desejava?.

Nos versos que compõem as estrofes 29, 30, 31 e 32, seguem-se imagens do comércio lisboeta, visualizando as casas de comércio de tecidos e as pessoas abastadas que as frequientavam. Tudo isso se finalizando na imagem fúnebre do quarto verso da $32^{\mathrm{a}}$ estrofe. “Tornam-se mausoléus as armações fulgentes". (VERDE, 1964, p.108)

E com isso o comércio fecha e a cidade torna-se um túmulo. Imagens de onde sai o título para a quarta e última parte do poema, "Horas Mortas", provavelmente referência às horas em que a maior parte da cidade dorme. Esta parte inicia-se com quatro versos obscuros.

O tecto fundo de oxigénio, de ar,

Estende-se ao comprido, ao meio das trapeiras;

Vêm lágrimas de luz dos astros com olheiras,

Enleva-me a quimera azul de transmigrar. (VERDE, 1964, p.109)

O que podemos depreender destes versos? O eu lírico é levado a um devaneio ou literalmente, em se falando de gírias, a "viajar". A imaginação, que para ele é azul, o arrebata, o envolve, o cativa, o absorve, o extasia fazendo com que ele transmigre. A imaginação, naquelas "horas mortas", o acompanha substituindo, talvez, o vazio deixado pela agitação da cidade. E é com ela, à flor da pele, que o eu lírico continua sua marcha. Marcha esta que, passando pela estrofe 35, nos leva a quatro versos que fornecem mais elementos para pensarmos a origem deste sentimento dum ocidental.

E eu sigo, como as linhas de uma pauta,

A dupla correnteza augusta das fachadas;

Pois sobem, no silêncio, infaustas e trinadas,

As notas pastoris de uma longínqua flauta. (VERDE, 1964, p.109)

Esses versos nos remetem à primeira estrofe desta parte do poema. A imaginação que 
lá aflorou parece que aqui provoca seus efeitos. O eu lírico, em sua constante marcha pela cidade, ouve o som de um flauta. Mas se estamos nas "horas mortas", quase madrugada, e não podemos esquecer, em meio ao silêncio, de onde provem essa música? São, como nos diz o próprio poeta, "notas pastoris" de uma flauta longínqua. Ora, parece que a imaginação do poeta o levou para um passado, o transmigrou para outro lugar que não a Lisboa do século XIX. Os versos subseqüentes parecem confirmar isso.

\footnotetext{
Se eu não morresse, nunca! E eternamente

Buscasse e conseguisse a perfeição das cousas!

Esqueço-me a prever castíssimas esposas,

Que aninhem em mansões de vidro transparente!

Ó nossos filhos! Que de sonhos ágeis,

Pousando, vos trarão a nitidez às vidas!

Eu quero as vossas mães e irmãs estremecidas,

Numas habitações translúcidas e frágeis.
}

Ah! Como a raça ruiva do porvir,

E as frotas dos avós, e os nômades ardentes

Nós vamos explorar todos os continentes

E pelas vastidões aquáticas seguir! (VERDE, 1964, p.110)

Parece que o eu lírico, imbuído da certeza de sua morte, evoca para as gerações futuras aspectos, que para ele são positivos, de um passado glorioso. Seu desejo de mudança, frente às coisas que ele percebeu na sua "viagem" pela cidade, se cristaliza nesses versos. Sua insatisfação frente à situação captada pela sua sensibilidade se expressa nos versos dirigidos à geração subseqüente à dele e de seus contemporâneos. Ele clama a "sonhos ágeis" para que eles tragam "nitidez às vidas" dessa futura geração. Essa agilidade dos sonhos parece concordar com a agilidade agregada, nos versos subseqüentes, às gerações passadas, que seriam os avós e suas frotas e os nômades ardentes. Em suma, parece que o desejo do poeta é que as gerações futuras repitam os feitos das gerações passadas, o que fica evidente no último verso transcrito acima.

Saindo desse devaneio, ou transmigração ao passado, o poeta se depara com a realidade por ele vivida. $\mathrm{O}$ tom profético dá lugar ao velho tom melancólico, evidenciando a sua causa.

\footnotetext{
Mas se vivemos, os emparedados,

Sem árvores, no vale escuro das muralhas!...

Julgo avistar, na treva, as folhas das navalhas

E os gritos de socorro ouvir estrangulados. •

E nestes nebulosos corredores

Nauseiam-me, surgindo, os ventres das tabernas;

Na volta, com saudade, e aos bordos sobre as pernas,

Cantam, de braço dado, uns tristes bebedores. (VERDE, 1964, p.110)
}

Parece claro, agora, que o tom de melancolia provém desse sentimento de clausura que 
o eu lírico sente diante do fenômeno cidade, como nos atestam os dois primeiros versos da primeira estrofe acima. O poeta se dirige (não esquecendo) aos moradores de Lisboa e os adjetiva de emparedados, e descreve a cidade como "vale escuro das muralhas!". Assim, num tom melancólico, ele se encaminha para o desfecho do poema. Seus sonhos de grandeza, destruídos diante das cenas da realidade que ele descreveu, e esse sentimento de aprisionamento dentro da cidade o levam a esses versos finais:

E, enorme, nesta massa irregular

De prédios sepulcrais, com dimensões de montes,

A dor humana busca os amplos horizontes,

E tem marés, de fel, como um sinistro mar! (VERDE, 1964, p.111)

Nota-se que os versos finais de "O sentimento dum Ocidental" sintetizam o sentimento de melancolia frente à cidade e todos os sentimentos que esta desperta no eu lírico. Mas, além disso, nos remetem a uma imagem, que pensamos ser de fuga, frente a esses sentimentos. $\mathrm{O}$ poeta nos diz que pelos amplos horizontes a dor humana se vai. A dor humana obviamente é essa que captamos durante a análise do texto, mas para onde ela seguiria? Para onde levam esses amplos horizontes? A resposta, iremos procurar no próximo texto.

\section{Eu indo ao pampa, o pampa indo em mim}

O poema/canção "Ramilonga" de Vitor Ramil situa-se no tempo como algo surgido mais de um século depois de "O Sentimento dum Ocidental" de Cesário Verde. Porém, tematicamente, vislumbram-se semelhanças nítidas. As imagens urbanas descritas (que remetem à cidade de Porto Alegre), a atmosfera suspensa, e um sentimento de melancolia que, assim como em Cesário, perpassam o texto. Este se inicia assim:

Chove na tarde fria de Porto Alegre

Trago sozinho o verde do chimarrão

Olho o cotidiano, sei que vou embora

Nunca mais, nunca mais

Chega em ondas a música da cidade

Também eu me transformo numa canção

Ares de milonga vão e me carregam

Por aí, por aí

Ramilonga, Ramilonga .(RAMIL, 2005.)

Vemos, nos versos acima, a pintura de uma atmosfera suspensa. A tarde é fria e chuvosa. O eu lírico, sozinho, "traga o verde do chimarrão"3. Mergulhado nesta solidão, ele

\footnotetext{
${ }^{3}$ A solidão está intimamente vinculada ao hábito gaúcho de tomar chimarrão. Na lenda, de domínio popular, o chimarrão surge com um presente dado por um deus a um índio. Um velho cacique, vendo sua filha casar-se com um guerreiro da tribo, se depara com o fato de não mais ter companhia. Queixando-se ao seu deus, este lhe indica uma planta, que, segundo ele, transformada numa espécie de chá (chimarrão), traria conforto e companhia ao velho cacique.
} 
ouve a música da cidade à sua volta. Frente a essa música, que nada mais é que os sons da movimentação da cidade, o eu lírico nos declara que ele também se transforma numa canção. Ele sofre uma metamorfose, e se mescla com essa música. Daí provém o refrão do poema "Ramilonga, Ramilonga". Se pensarmos um pouco a respeito, vemos que essa palavra é fruto da metamorfose sofrida pelo eu lírico do poeta (ela provem da junção de seu nome, Ramil, mais a soma de um ritmo musical, a Milonga ${ }^{4}$ ). A Milonga, assim como nos descreve Sosa,

é um comentário da vida, é uma trova, é um tipo de composição centrada na despedida, em suas contingências, compensações, sombras e perdas. E, por essa razão, talvez num plano relevante, a milonga - e aqui não mais a forma musical milonga, mas sim os ares, a atmosfera da milonga - envolva um tempo passado, seja em lembranças, seja em reflexionamento da vida. (SOSA, 2004, p.6).

Assim encarados, os versos do eu lírico nos remetem a um sentimento introspectivo. Os ares de milonga, aos quais ele se refere, tomam conta da cidade e o levam a uma viagem por sobre ela. Viagem esta que é feita num tom de despedida, como nos demonstra o verso recorrente, "Nunca mais, nunca mais".

Sobrevôo os telhados da Bela Vista

Na Chácara das Pedras vou me perder

Noites no Rio Branco, tardes no Bom Fim

Nunca mais, nunca mais (RAMIL, 2005.)

Nestes versos, de estrema síntese, o eu lírico descreve toda uma imagem da cidade e das características de alguns de seus bairros mais famosos. Os dois primeiros são áreas residenciais, o terceiro possui uma vida noturna agitada e o último é caracterizado, no imaginário da cidade, como um lugar de passeio e descanso devido ao parque que lá se encontra. Seguindo no poema, nos defrontamos com esses versos.

O trânsito em transe intenso antecipa a noite

Riscando estrelas no bronze do temporal

Ares de milonga vão e me carregam

Por aí, por aí

Ramilonga, Ramilonga

O tango dos guarda-chuvas na Praça XV

Confere elegância ao passo da multidão

Triste lambe-lambe, aquém e além do tempo

Nunca mais, nunca mais (RAMIL, 2005.)

A atmosfera suspensa se intensifica, o eu lírico nos descreve o anoitecer na cidade e o fluxo contínuo do trânsito. Outro aspecto dessa atmosfera melancólica é a imagem do temporal, que intensifica os ares de milonga, entenda-se, como nos descreve Sosa, ares que remetem ao passado. Estes ares continuam a levar o eu lírico a um tour pela cidade. A

\footnotetext{
${ }^{4}$ A Milonga é um ritmo musical característico da região denominada como Pampa. Sua cadência tenta repetir o ritmo melancólico do vento, típico da região, chamado Minuano.
} 
imagem dos guarda-chuvas, ou seja, das pessoas numa praça, é descrita com outra metáfora musical; os guarda-chuvas dançam Tango, ritmo trágico, característico da cultura argentina. Após essa imagem nos deparamos com um verso interessante, onde o eu lírico mescla passado com presente, na imagem do lambe-lambe, que segundo o poeta está "aquém e além do tempo". Quem seria este fotógrafo de rua? Quem sabe o próprio eu lírico... Seguindo,

\author{
Do alto da torre a água do rio é limpa \\ Guaíba deserto, barcos que não estão \\ Ares de milonga vão e me carregam \\ Por aí, por aí \\ Ramilonga, Ramilonga \\ Ruas molhadas, ruas da flor lilás \\ Ruas de um anarquista noturno \\ Ruas do Armando, Ruas do Quintana \\ Nunca mais, nunca mais (RAMIL, 2005.)
}

Temos nestes versos imagens da cidade de Porto Alegre, o cais, a torre (provável referência à torre da Usina do Gasômetro, localizada à beira do rio Guaíba e, hoje, centro cultural da cidade), as ruas (que em sua maioria são arborizadas) que são posses, segundo o eu lírico, de outras duas personagens, que antes dele cantaram a cidade. Encaminhando-se para o fim do poema temos o eu lírico dizendo o seguinte,

\footnotetext{
Do alto da bronze eu vou pra cidade baixa

Depois as estradas, praias e morros

Ares de milonga vão e me carregam

Por aí, por aí

Ramilonga, Ramilonga (RAMIL, 2005.)
}

Os dois primeiros versos desta parte nos remetem a uma imagem que vai para além da cidade de Porto Alegre, pois esta em sua geografia acaba antes dos morros descritos pelo eu lírico. Este dado nos leva a crer que ele vai, carregado pelos ares de milonga rumo ao horizonte. Fato este que nos remete aos versos finais do poema

\footnotetext{
Vaga visão, viajo e antevejo a inveja

De quem descobrir a forma com que me fui

Ares de milonga sobre Porto Alegre

Nada mais, nada mais. (RAMIL, 2005.)
}

Para onde se foi o eu lírico? A forma ele nos explicitou, ele se transformou numa canção, numa milonga, e se relembrarmos as palavras de Sosa a respeito desse ritmo musical, vemos que ele se caracteriza por uma reflexão do passado. Sendo assim, parece-nos que o eu lírico, metamorfoseado em milonga, se vai pelo horizonte. Viagem essa que, segundo ele, despertará inveja nos que ficaram presos a esse presente descrito no poema, a essa cidade, a essa atmosfera, a esse tempo. Mas, para onde foi o eu lírico? 


\section{Ramilonga, sentimento dum Ocidental}

Segue-se agora a tentativa de um cotejo entre os poemas acima analisados. Parece claro, após essa análise, que em ambos temos elementos em comum. Temos a temática da cidade (Lisboa, em Cesário e Porto Alegre, em Ramil), o sentimento de melancolia que perpassa os textos e a tentativa de fuga, pelo horizonte, para além do contexto vivido.

Parece claro, também, que o sentimento de melancolia provém, nos dois poemas, do posicionamento de ambos os poetas frente à cidade e seu fluxo. Ambos estranham, em suas "viagens", "passeios", a figura da cidade e seu ritmo. Suas sensibilidades não se encaixam nestes ritmos, por isso a fuga. O horizonte se torna destino, em ambos, para seus sonhos e dores. E é aí que vislumbramos um ponto em comum. A tese que se afigura é de que, em ambos os poetas, temos o horizonte como metáfora, imagem de um passado grandioso, pastoril, para onde ambos apontam como saída do sentimento de melancolia, uma saída saudosista. Vislumbra-se isto, se nos valermos de toda a obra de ambos os poetas, principalmente, do poema "Nós" de Cesário e do poema/canção "Indo ao Pampa" de Ramil. Tendo em mente esses novos dados, prossigo.

Pensando Ramil e sua obra, aqui encarada como o disco Ramilonga, achamos argumentos para corroborar a tese de que ele, no poema "Ramilonga", aponta para uma fuga ao passado. Voltando um pouco e relendo o desfecho do poema nos deparamos com os seguintes versos:

Vaga visão, viajo e antevejo a inveja

De quem descobrir a forma com que me fui

Ares de milonga sobre Porto Alegre

Nada mais, nada mais. (RAMIL, 2005.)

Assim como já dissemos acima, a pergunta que nos resta fazer diante destes versos é: para onde se vai o eu lírico? Parece-nos que a resposta, nós a encontramos no poema seguinte, dentro da obra Ramilonga $a^{5}$, chamado "Indo ao Pampa". Ali nos deparamos com os seguintes versos:

Eu indo ao pampa

O pampa indo em mim

Quase ano 2.000

Mas de repente avanço

A mil e oitocentos e trinta e oito

Eu digo avanço porque é claro

\footnotetext{
${ }^{5}$ Aqui é interessante ter em mente que sigo nessa abordagem a idéia de que o disco "Ramilonga: a Estética do Frio" é uma obra conceitual, significativa num todo. Não faz sentido falarmos dele se não levarmos em conta todas as faixas que o compõem.
} 
Que os homens por ali

Estão pra lá dos homens

Do ano 2.000 (RAMIL, 2005.)

Ora, temos aqui a resposta textual a nossa pergunta. Se em "Ramilonga" temos um tom de despedida do eu lírico frente à cidade e a sua atmosfera, aqui temos o destino deste mesmo eu lírico. Ele se transportou para o passado. Um passado que retrocede mais de 150 anos o presente de onde parte o eu lírico. Neste passado parece que o poeta se encontra enquanto pessoa, pois a carga de valor que ele atribui aos homens desse tempo excede à que ele vislumbra nas pessoas do tempo de onde ele partiu.

Passando para Cesário e "O Sentimento dum Ocidental", lembramos que lá também aparece uma carga valorativa semelhante. Em seu delírio, o eu lírico canta os feitos grandiosos das gerações passadas e deseja que as gerações futuras os repitam.

Olhando para o todo da obra do poeta português, encontramos um poema significativo para nossa análise e tese. Trata-se do poema intitulado "Nós". Este poema, apesar de pertencer à face realista do poeta, possui fortes traços românticos e até árcades, outras faces presentes na poesia de Cesário. Em "Nós", temos narrada uma história de fuga da cidade de Lisboa devido a uma epidemia de cólera. O eu lírico se refugia, ainda criança, num sítio longe do caos urbano. Segue-se então uma longa descrição de uma vida simples voltada às coisas do campo. Mesmo sendo uma descrição realista, possui lapsos de ufanismo pastoril. Este aparece como ataque às cidades

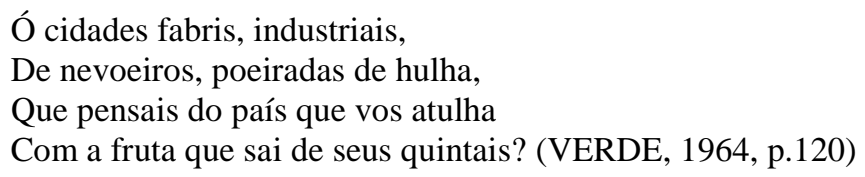

Temos um contraponto entre as cidades industriais, que o texto nos faz identificar como sendo inglesas, e um país majoritariamente rural (Portugal). Assim chegamos a notar um ufanismo em torno do nacional, um sentimento nacionalista extremado, estritamente vinculado ao modo de vida e às coisas do meio rural português. Nessa linha, temos os significativos versos que se seguem:

Anglo-saxônicos, tendes que invejar!

Ricos suicidas, comparai conosco!

Aqui tudo espontâneo, alegre, tosco,

Facílimo, evidente, salutar!

Oponde às regiões que dão os vinhos

Vossos montes de escórias inda quentes!

$\mathrm{E}$ as fabril oficinas estridentes

Às nossas tecelagens e moinhos!

E ó condados mineiros! Extensões

Carboníferas! Profundas galerias! 
Fábricas a vapor! Cutelarias!

E mecânicas, tristes fiações!

Bem sei que preparais correctamente

$\mathrm{O}$ aço e a seda, as lâminas e o estofo

Tudo o que há de mais dúctil, de mais fofo,

Tudo o que há de mais rijo e resistente!

Mas isso tudo é falso, é maquinal,

Sem vida, como um círculo ou um quadrado,

Com essa perfeição do fabricado,

Sem o ritmo do vivo e do real!

E cá o santo sol, sobre isso tudo,

Faz conceber as verdes ribanceiras;

Lança as rosáceas belas e fruteiras

Nas searas de trigo palhagudo!

Uma aldeia daqui é mais feliz,

Londres sombria, em que cintila corte!...

Mesmo que tu, que vives a compor-te,

Grande seio arquejante de Paris!... (VERDE, 1964, p.129 - 130)

Apesar desse tom grandioso em torno do nacional, que é para o eu lírico a vida no campo que supera as possibilidades da vida nas grandes metrópoles, ele não perde o tom realista, como podemos comprovar nesses versos.

Hoje eu sei quanto custam a criar

As cepas, desde que eu as podo e empo.

Ah! O campo não é um passatempo

Com bucolismos, rouxinóis, luar.

A nós que tudo nos rouba e nos dizima:

O rapazio, o imposto, as pardaladas,

As osgas peçonhentas, achatadas,

$\mathrm{E}$ as abelhas que engordam na vindima.

$[\ldots]$

Para a Terra parir há-de ter dor

E é para obter as ásperas verdades,

Que os agrónomos cursam nas cidades,

E, ás suas custas, aprende o lavrador. (VERDE, 1964, p.137 - 138)

Esse tom realista segue até o final do poema, marcado por uma tomada de valor frente à cidade para a qual o eu lírico se vê obrigado a voltar. Suas palavras diante desse episódio são: "Tínhamos nós voltado à capital maldita,/ Eu vinha de polir isto tranqüilamente" (VERDE, 1964, p.144). Diante dessas palavras e do que tentamos até agora elucidar, vemos que a imagem do eu lírico sobre a cidade não é de forma alguma favorável. Muito pelo contrário, parece-nos claro que a ele agrada muito mais a vida no campo, apesar da forma realista com a qual ele vislumbra esse tipo de vida dura, sofrida, cheia de altos e baixos.

Remetamo-nos a "O Sentimento dum Ocidental!" e a "Ramilonga". Parece que, em 
ambos os poemas, e principalmente tendo em vista o que foi garimpado no restante das obras de ambos os poetas, surge camuflada no sentimento de melancolia essa visão ufanista, ou melhor, essa visão positiva do passado e da vida campeira. Assim, Cesário, ao ver seu sonho de glórias nacionais do passado sendo esmagado pela dura realidade do presente, refugia-se num ideal de vida simples ligado ao campo em oposição à vida agitada e artificial das cidades. Em Ramil isso se realiza na fantástica volta no tempo realizada pelo eu lírico, que se transporta ao século XIX. Para um tempo de guerras, mas um tempo glorioso, "onde as idéias não são cegas num espaço sem ar" (RAMIL, 2005.), ou seja, onde a vida ainda tem um motivo, um ideal.

"Ramilonga" tem esse tom saudosista, nostálgico, mesmo porque se trata de um poema musicado, transformado em Milonga, o que acarreta levar consigo toda a carga desse ritmo musical, elemento que não se faz presente quando falamos de "O Sentimento dum Ocidental" e que no todo faz diferença, principalmente por acentuar esse tom de melancolia. Mas, se pensarmos bem, ou melhor, se imaginarmos bem, se fecharmos os olhos e nos transportarmos para a Lisboa do século XIX, suas ruas, sua turba, seu movimento, o Tejo correndo rumo ao mar, enfim todas as cenas "filmadas" por Cesário; e se formos imaginar uma trilha sonora para esse documentário, alguém teria dúvidas em escolher um Fado, este ritmo tão melancólico e marcante da cultura portuguesa?

Imaginando assim, colocamos os dois poemas em pé de igualdade. E podemos entretecê-los perfeitamente. Daí convém dizer que o que Cesário Verde cristalizou em "O Sentimento dum Ocidental", toda a melancolia frente à implementação da modernidade e das mudanças que ela trouxe, Ramil também sente em "Ramilonga", só que de uma forma definitiva, pois a modernidade nele é um fenômeno instalado, mas não melhor compreendido.

As atmosferas suspensas (das tardes chuvosas ou do gás extravasado), os sons (da música da cidade ou do Tejo esvaindo), as cores (o bronze do temporal ou o cinza dos prédios em construção), tudo isso parece que abre uma espécie de portal dimensional, onde o tempo se distorce e onde os sentimentos acham uma fuga rumo ao horizonte, rumo ao passado, rumo ao coração daquele leitor/ouvinte/sonhador que, como os poetas, procura se entender frente a essa atmosfera moderna.

\section{Referências}

BERMAN, Marshall. Tudo que é sólido desmancha no ar. São Paulo: Companhia das Letras, 1986. 
FISCHER, Luís Augusto. Para Fazer diferença: ensaios. Porto Alegre: Artes e Ofícios, 1998.

MATTOSO, José. História de Portugual. Lisboa: Estampa, 1990.

PESAVENTO, Sandra Jatahy. A Pedra e o Sonho: Os caminhos do Imaginário Urbano. In: O Imaginário da Cidade. Porto Alegre: Ed. Universidade/UFRGS, 1999. p. 7 27.

RAMIL, Vitor. A Estética do Frio. In: Nós, os gaúchos. Porto Alegre. Editora da Universidade/UFRGS. 1998.

Ramilonga: A Estética do Frio. Satolep/Fumproarte. Gravação: 1997. 1 CD com 11 Faixas (46mim54seg).

. Ramilonga: A Estética do Frio. Atualizado em 18 de setembro de 2006. Disponível em:«http://www.vitorramil.com.br/discos/ramilonga.htm»18 de setembro de 2005.

SOSA, Marcos. Ramilonga, de Vitor Ramil - Estudo da Canção. 2004. 36 f. Monografia (graduado) - Formado/UFRGS, Porto Alegre, RS. 2004.

VERDE, Cesário. Obra Completa de Cesário Verde. Lisboa: Portugália,1964. 